\title{
Core values as a management control in the construction of "sustainable development"
}

\author{
Stephen Jollands \\ University of Exeter Business School \\ Exeter, Devon EX4 4PU \\ United Kingdom
}

Email: s.e.jollands@exeter.ac.uk

\author{
Chris Akroyd \\ College of Business, Oregon State University \\ Austin Hall, Corvallis, OR, 97333 \\ United States of America \\ Email: chris.akroyd@bus.oregonstate.edu
}

and

\author{
Norio Sawabe \\ Graduate School of Management, Kyoto University \\ Yoshidahonmachi, Sakyo Ward, \\ Kyoto, 606-8317 \\ Japan \\ Email: sawabe@econ.kyoto-u.ac.jp
}

Acknowledgements - This paper has benefited from the helpful comments on earlier versions made by John Burns, Habib Mahama, Kohji Yoshikawa, Casey Rowe, Takaharu Kawai, participants at the $8^{\text {th }}$ International Management Control Research Conference, participants at MONFORMA 2010, participants at the 4th New Zealand Management Accounting Conference, participants at the 2013 Management Accounting Section Research and Case Conference, and seminar participants at the Department of Operations Management, Copenhagen Business School, Department of Accounting, University of Exeter Business School, and Department of Accounting, Doshisha University. We would especially like to thank the anonymous reviewers for their constructive and insightful comments that have allowed us to improve the paper. 


\title{
Core values as a management control in the construction of "sustainable development"
}

\begin{abstract}
Purpose: This paper examines a management control constructed by senior managers, a core value focused on sustainability, as it travels through time and space. The criticality of sustainable development suggests the need to understand the effects that core values have on organisational actions.
\end{abstract}

Design/methodology/approach: We utilise a case study methodology carried out at a multinational organisation. Our analysis was informed by actor-network theory which allowed us to place the organisation's sustainability focused core value at the centre of our research.

Findings: We found that management control, in the form of a sustainability focused core value, took on an active role in the case organisation. This enabled the opening of space and time that allowed actors to step forward and take action in relation to sustainable development. We show how the core value mobilised individual actors at specific points in time but did not enrol enough collective support to continue its travel. The resulting activities, though, provided a construction of sustainable development within the organisation more in line with traditional profit seeking objectives rather than in relation to sustainability objectives, such as inter- and intra-generational equity.

Research limitations/implications: These findings suggest possibilities for future research that examines the active role that management controls may take within sustainable development.

Originality/value: This paper shows the active role a management control, a sustainability focused core value, took within an organisation. This builds on the research that examines management control in relation to sustainability issues and sustainable development as well as the literature that examines core values.

Keywords: core values, management control, sustainability, sustainable development, actornetwork theory

Article Classification: Research paper 
Many years ago the first author worked at nights as a croupier at a casino to pay for his undergraduate studies. Starting or finishing a shift or going to or returning from a break required climbing a set of stairs from the administrative floor below to the gaming floor above. Every time he made this trip he puzzled at the 'Mission Statement' of the casino that was displayed half way up these steps. It contained many of the casino's stated core values. These short textual statements referred to such lofty goals as "creating an exciting and fun environment that thrills and amazes all our guests" and "providing a safe and relaxed environment in which all our guests feel appreciated". Stepping out onto the gaming floor his eyes would become full of a scene that seemed far removed from the lofty statements of the core values. A typical shift would include overly drunk people, fights breaking out, people swearing in every conceivable language, cigarette smoke swirling like an ever present mist, people relying on superstitious beliefs to overcome the statistical odds stacked against them, and generally an overcasting gloom derived from the mass of people that "unbelievably" had lost all their money again. In short the casino was everything except what a James Bond film would suggest. This made the first author curious. What did these stated core values have to do with the everyday practices of the gaming operations? Were they merely rhetoric aimed at external pressure groups and to salve the conscious of well paid executives? What is now of interest is that the core values across a wide variety of organisations contain these kinds of optimistic statements in regards to 'sustainability' and 'sustainable development'. The following paper covers research that was sparked by an old curiosity finding a more prevalent focus.

\section{Introduction}

Sustainability and sustainable development are contested and ambiguous concepts which can be understood in many different ways (Ball and Milne, 2005, Bebbington, 2001, Byrch et al., 2007, Cairns, 2001). For the purposes of this paper we define sustainability as a state in which resources from the ecosphere can naturally be replenished at the same or higher rate than extraction, with an equitable distribution of those resources within and between generations (Ball and Milne, 2005, Milne and Gray, 2007). This perspective recognises the need to live equitably within the planetary boundaries that limit the scope and scale of economic activity (Gladwin et al., 1995, Rockstrom et al., 2009, Whiteman et al., 2013). Sustainable development, therefore, is the process through which sustainability is achieved (Bebbington and Gray, 2001, Bebbington and Larrinaga, 2014, Gray, 2010, Milne et al., 2006).

The issues of sustainability and how to implement sustainable development are arguably the greatest challenges facing society and organisations today (Gray, 2010, Wackernagel and Rees, 1996). It is not possible to definitively prove (Dryzek, 1997) whether or by how much we are exceeding the carrying capacity of the ecosphere (Arrow et al., 1995). However, contemporary indicators demonstrate that we are moving towards a more unsustainable state rather than towards a state of sustainability (IPCC, 2014, WWF - World Wide Fund for Nature, 2014). There is a growing realisation that the way in which the economy, and organisations within it, are organised will need to change (for example Simons et al., 2002). That is, the implementation of sustainable development will require a new approach to how we organise our economies and organisations that become a natural part of daily practices (Bebbington and Larrinaga, 2014, Birkin, 2000).

To date, however, research into accounting for sustainable development has been dominated by a focus on reporting (Bebbington and Larrinaga, 2014, Milne, 2007, Owen, 
2008, Unerman and Chapman, 2014). There have been a limited number of studies that examine the efforts within organisations to address sustainable development. Within these studies, a smaller subset utilise the lens of management control. This is surprising given that any efforts within an organisation to implement sustainable development will be reliant on the information flows facilitated by management controls (Contrafatto and Burns, 2013). One contributing factor for this lack of focus may be that the management controls currently utilised are inconsistent with sustainability and sustainable development (Ball and Milne, 2005). However, management controls that address sustainability issues have the potential to assist with the lack of ecological literacy that traditional management controls do not facilitate (Ball, 2007, Ball and Milne, 2005).

Another contributing factor may be that the limited research that utilises a management control perspective demonstrates a lack of engagement with sustainability and sustainable development (Bebbington and Larrinaga, 2014, Bebbington and Thomson, 2013). That is, while their stated aims are generally in regard to sustainable development, they approach this from and focus upon the accounting implications (Bebbington and Larrinaga, 2014, Gray, 2010). Typically they reproduce the definition provided by the 'Brundtland Report' (World Commission on Environment and Development, 1987) while ignoring the broader literature and thinking around sustainability and sustainable development (Bebbington and Thomson, 2013).

The purpose of this paper is to examine a specific management control, a sustainability focused core value as it travels through time and space. Core values are the short textual or verbal representations created by senior managers in an attempt to signal their intentions (Simons, 1994, Simons, 1995). We focus on who and what the core value enrols, manipulates, corrals around it, and the efforts that are required to continue its movement. Specifically we seek to understand whether and how, over time, the core value 'promotes' and instils (or not) sustainability and sustainable development within our case organisation. That is, we examine whether the use of a core value that focuses on sustainability assists or deters from efforts by organisational actors to address these issues. If core values are merely rhetoric aimed at external pressure groups or salving the conscious of well paid executives then they are likely to deter the efforts of organisational actors. However, as core values often become part of the public domain there is also a risk for organisational actors in not following through on the promises they make. With scarce prior literature on core values, and none that specifically examines them in relation to sustainability issues (but see Norris and O'Dwyer, 2004), it is not clear whether and how these impact (or not) the everyday practices of organisational actors.

Data for this study was collected through an in-depth longitudinal case study at an organisation, 'Kiwi'[1], which introduced an informal core value that focused on sustainability. The focus on an informal core value, as opposed to one that is formalised within, for instance, a mission statement, is appropriate given that such types of controls, while often being overshadowed by formal controls (Pitkänen and Lukka, 2011), are effective in eliciting responsible decision making by managers (Norris and O'Dwyer, 2004). In order to analyse the data gathered we utilise an actor-network theory (ANT) based perspective (Callon, 1986b, Latour, 1987, Latour, 2005, Law, 1992). Its use allows us to place at the centre of our analysis (Justesen and Mouritsen, 2011) the sustainability core value at Kiwi and follow it (Latour, 1987) in order to observe the controversies it faced (trials of strength), who it enrols to speak on its behalf (spokesperson) and what other actors are associated with it (enrolled) in order that it can continue to travel through space and time (Callon, 1986b). ANT is an underutilised theoretical lens within the accounting focused sustainability literature (Barter and Bebbington, 2013) and therefore has potential to assist in highlighting new understandings (Bebbington and Larrinaga, 2014, Unerman and Chapman, 2014). 
Our case study shows that not only can management controls be used by organisational actors to create space and time for them to undertake activities in relation to sustainable development (Ball, 2007) but also the core value created time and space to allow actors to come forward to act in previously no go areas related to sustainable development. This illustrates the active role that management controls can undertake within sustainable development.

We also show that the core value mobilised individual actors but failed to enrol enough collective support to continue its travel. The resulting actions were largely in terms of profit seeking rather than sustainability and sustainable development (Contrafatto and Burns, 2013, Norris and O'Dwyer, 2004, Spence and Rinaldi, 2014). This illustrates that the lack of engagement with sustainability and sustainable development within the management control literature (Bebbington and Larrinaga, 2014, Unerman and Chapman, 2014) may be because these practices do not currently exist in organisations. This suggests that future efforts may require researchers to arm themselves with the requisite knowledge of sustainability and sustainable development (Bebbington and Larrinaga, 2014, Bebbington and Thomson, 2013) and actively engage with organisations so that the ecological literacy of practitioners can be improved (Ball and Milne, 2005)

The remainder of the paper is organised as follows. In the next section we provide a brief overview of the literature that underlies the development of this research. We then in the following section provide an overview of ANT and how it relates to this research. This is followed by a section providing an overview of our case organisation and research method. We then have three sections that respectively trace the travels of the core value at our case organisation, provide a discussion and conclude.

\section{Literature Review}

Core values are the management controls enrolled by senior managers to try construct a shared understanding of organisational purpose. Core values prompt actors (Adler and Borys, 1996, Ahrens and Chapman, 2004) to search for the actions that are in line with this purpose (Dent, 1991, Pratt and Beaulieu, 1992). They are designed to guide actors as to what is expected of them due to the inability to perfectly measure aspects of inputs, processes, and outputs (Ouchi, 1977, Ouchi, 1979). Simons (1994) defines core values as the key design variables that are utilised by senior managers to create a shared perspective within the organisation. However, despite the assertions of Simons and others (for example Flamholtz, 1983) that core values will create shared perspectives among actors, who are seen as passive (Gray, 1990, Tessier and Otley, 2012), there is little empirical evidence to suggest how they do this or whether this can be achieved. Because research typically examines core values that are already in place, little is known about how a core value travels through time and space, influencing the actions of organisational actors (Bruining et al., 2004, Mundy, 2010, Tuomela, 2005, Widener, 2007). Nixon and Burns (2005, p. 264) note that:

"One point that appears to emerge from the empirical reality [...] is that either the management control literature has over-emphasised the influence of diagnostic and interactive controls relative to informal, social controls (the belief and boundary systems of Simons (1995) framework), or the social controls are becoming more important in the 21 st century."

This suggests that with increasing issues of sustainability and uncertainty over how to implement sustainable development (Gray, 2010) examining the travels of a core values will create new knowledge about its' potential to expand organisational actors' attention to 
identifying new strategic opportunities that may assist (or deter) with these issues. However, it has been frequently stated that individual controls do not operate in isolation (Abernethy and Chua, 1996, Otley, 1980, Simons, 1995). Hence as we examine the core value we look to see what other actors, including other management controls, become implicated in its travels.

It should be noted that there has been limited research into management control and sustainability (for example Ball and Milne, 2005, Gond et al., 2012, Milne, 1996, Norris and O'Dwyer, 2004). Further, much of this literature (for example Gond et al., 2012) takes the ecological modernist view (Bebbington and Gray, 2001, Everett and Neu, 2000) of organisational change (Quattrone and Hopper, 2001, Andon et al., 2007). That is, there is an assumption that an organisation can utilise their management controls to undertake a linear path through time and space in a rational way from unsustainable practices to a state of sustainability. Further, traditional management controls may reinforce a 'business as usual' mentality that is unlikely to prompt the changes required to implement sustainable development and address the issues of sustainability (Ball and Milne, 2005).

We aim to build on an understanding of whether management controls that purport to be focused on sustainability assist or deter with an organisation's sustainable development efforts. Evidence suggests that these types of controls may open up possibilities for changes at the margin of 'business as usual' to occur. Ball's (2007) examination of the use of environmental accounting by organisational actors, labelled as 'workplace activists', to create space and time to allow them to undertake their activities exemplifies this approach. Ball's (2007) research highlights how actors within a Canadian City Council utilised management controls to illustrate to senior managers some of the sustainability issues the organisation was implicated in, which resulted in resourcing of efforts to address these issues. Hence Ball (2007) argued that there was a need to engage in research that developed further knowledge of the effects of these management controls on the daily practices of organisations. Ball (2007) also exemplifies, given that the actors at the Canadian City Council mobilised environmental reporting and quality of life indicators, the limited engagement in a broad set of management controls that purport to focus on sustainability.

As mentioned above the extant accounting for sustainability literature has been dominated by a focus on reporting. Hence, while there have been other areas of management control and sustainability examined, notably full cost accounting and related techniques (Antheaume, 2007, Bebbington et al., 2001, Fraser, 2012, Xing et al., 2009), these are generally examined in isolation from other management controls. Further, to date, none have examined core values, despite suggestions that these types of controls may have an important role to play (Nixon and Burns, 2005) and may also prompt greater levels of responsible decision making (Norris and O'Dwyer, 2004). Little is known, for instance, whether core values purporting to be focused on sustainability can assist with opening up other perspectives within an organisation beyond "institutional appropriation" and "organisational change" (Ball, 2007, Larrinaga-Gonzalez and Bebbington, 2001). Hence we examine the practices that surround the core value at Kiwi as it travels through time and space. We now turn, in the next section, to outlining the theoretical framing that we mobilise in our analysis of this case study.

\section{Theoretical Framing: Actor-Network Theory}

The use of actor-network theory (ANT) assists with placing the sustainability focused core value at the centre of the research (Justesen and Mouritsen, 2011). It helps us understand what management controls are, and allows us to examine how such objects need to corral others in order to continue to travel through time and space. While we know that management controls are part of the commonly observed daily practices of actors within organisations (Akroyd and Maguire, 2011) there are many competing understandings of what is a 
management control. Rather than mobilising one of the many competing definitions we do not presuppose what is to be included (or excluded) as a management control (Latour, 2005). Rather we follow (Latour, 1987) the core value at Kiwi to unravel its history (Callon, 1986a) and see what is assembled around it, what is corralled together as a result of its travels, look to see what controversies (trials of strength) it becomes embroiled in, and examine whether it assists or deters efforts to address sustainability issues. Hence what is to be assessed as a management control comes from the practices of the actors (Latour, 2005).

This focus of drawing from the practices of actors is demonstrated in Latour's (1991) example of the European hotel key. This example focuses on a hotel manager's efforts to reduce the loss of keys through prompting customers to leave them at reception prior to leaving the hotel. This requires the hotel manager to translate (Callon, 1986b, Latour, 2005) the will and intention of many different actors. The hotel manager deploys a number of means to enrol guests into this program. First the manager asks the receptionist to remind guests as they check in to leave their keys at reception when going out. Next a sign is placed near the door to remind guests as they leave the hotel. Finally a large, cumbersome weight is attached to the key, which acts on the guests by making their "pockets bulge and weighs down their handbags: they go to the front desk on their own accord to get rid of it" (Latour, 1991, p. 104).

The verbal reminder, sign, and weight are the actors enrolled by the manager to act upon guests in order to translate their actions into those that will implement the program of limiting the loss of keys. Therefore the verbal reminder, sign, and weight can each be labelled as management controls. Hence if a core value acts in a way that assists implementing the program of senior managers then it is a management control. However, as core values are usually stated in broad terms it is likely that managers will also utilise a number of other management controls to support their attempts at translation (Callon, 1986b, Latour, 2005). For instance without the verbal reminder and signs the likelihood is that some guests will not understand the hotel managers' intention. As a result they will take their keys with them rather than returning them to reception and experience displeasure at having to carry such a large and cumbersome object. Hence we see that together the verbal reminder, sign, and weight form a system of management controls.

This has two inter-connected implications for our research. First we need to examine what other management controls are assembled around the core value. Like all actors, core values do not gain their strength through being inherently good or effective but through their abilities to enrol and mobilise others (Mouritsen et al., 2009). Second we need to recognise that without the corralling of these other actors the core value itself will not be able to continue its travel through time and space (Latour, 1986). Therefore, we examine whether the core value acts as a 'mediator' which affects the way in which others would have acted or whether it is an 'intermediary' which is all but invisible due to the intentions of the managers passing through it unaffected (Latour, 1986, Latour, 2005). Hence the sign in combination with the verbal reminder and weight acts upon guests but without them it may become all but invisible to those leaving the hotel. We make no a priori assumptions that core values have an impact or indeed try to predict the magnitude or direction that this impact would take (Chua and Mahama, 2007, Latour, 2005, Mouritsen et al., 2010). As a mediator the core value may have many unanticipated effects as it changes, modifies or defies the intentions of the managers. For example, the weight may act upon a guest to prompt them to cut the weight loose from the key and in doing so being treasonous towards the manager's attempts at translation (Latour, 1991).

This recognises that the sustainability focused core value at Kiwi is a different actor than the concepts of sustainability or sustainable development. That is the former is a management control enrolled in senior managers attempts to implement their programs while 
the latter are contentious and ambiguous concepts (Ball and Milne, 2005, Milne, 1996, Gray, 2010) that focus on the relationship between the use of resources from the ecology and the sustainability of the human species (Bebbington, 2001, Milne and Gray, 2007, Wackernagel and Rees, 1996). However, all actors construct themselves with and against other actors (Callon and Law, 2005) with the network around them providing relevance (Mouritsen et al., 2010). Hence the actions that are prompted by the core value at Kiwi relate to and are given meaning in relation to sustainability and sustainable development (Miller and Napier, 1993, Quattrone and Hopper, 2001). This, however, does not correlate to the core value prompting action that addresses sustainability issues or implements sustainable development, but rather the actions that are prompted may be seen to assist or deter these efforts.

Given that the core value is stated in broad terms suggests that as it assembles, corrals, and enrols actors around it this will be an exercise of collective experimentation (Muniesa and Callon, 2007). As it is stated in broad terms, what is required to be assembled, corralled, and enrolled in order to allow it to travel will not be known beforehand and therefore will require research "in the wild". In other words, it requires research where the outcome is of importance due to it directly acting on the researcher (Callon and Rabeharisoa, 2003). It is a process of understanding why some actors are enrolled and enable the core value to continue to travel while other actors may inhibit this possibility (Muniesa and Callon, 2007). Hence, 'success' of such experimentations are never guaranteed but for the core value to continue it must assemble, corral, and enrol others (Callon, 1986a).

When an actor travels, such as the core value at Kiwi, through enrolling many others around it, this creates relationally-dependent change (Andon et al., 2007). That is, the experimentation will occur at multiple spaces and times within the organisation, requiring the involvement of many rather than a 'powerful' few (Briers and Chua, 2001). This conceptualisation of change counters a rational, predetermined, and centre orientated understanding and, thereby, recognises organisational drift (Quattrone and Hopper, 2001). Further, "drift reflects the inability of change agents to sufficiently control all contextual elements to achieve desired ends" (Andon et al., 2007, p. 277). Hence, even though senior managers enrol core values to prompt experimentation in a way where their intentions are translated into action, the resulting change may be unpredictable given the influence of the large number of actors, both human and non-human, involved. We now turn to providing an overview of the case organisation, the data we collected, and how we analysed this data.

\section{Research design and methods}

We use a case study method focusing on an organisation, Kiwi, which enrolled a core value in its attempts to address sustainability issues. Kiwi is the New Zealand manufacturer of a large well known multi-national organisation which competes in the fast moving consumer goods industry. At the time of this research Kiwi employed approximately one thousand people across sixteen sites located throughout New Zealand. Kiwi competes in all product lines within its market segment and is the market leader in two of these. It offers a range of internationally recognised brands along with local brands including one that is widely recognised as a New Zealand icon.

Kiwi operates as if it is a wholly New Zealand owned company, as demonstrated by its employee proposition 'Refreshingly Kiwi'. However, legally it is the New Zealand operations of an Australian listed company, 'Koala'. Koala's head office is in Sydney, Australia. Along with operations in New Zealand and Australia they also operate in Fiji, Papua New Guinea, and Indonesia. Across these countries, Koala employs over fifteen thousand people, has over seven hundred thousand active customers who provide them with access to over two hundred and sixty five million consumers. In 2009 Koala had revenue of 
just over four and a half billion Australian dollars and EBIT of close to eight hundred million Australian dollars.

Koala is in turn thirty percent owned by a USA based company, 'Eagle', on whom they are reliant for global marketing and the secret ingredient of their most famous product. Eagle has over three hundred companies, of which Koala is one, manufacturing its products in over two hundred countries. Through their thirty percent stake in Koala, Eagle has the right to appoint two out of the eight directors of Koala. Hence, Eagle has significant influence over Koala's operations. Thus, when Eagle signalled sustainability as an important issue that should be engaged with, Koala were also compelled to begin to understand what this entailed for their operations.

The data was collected between June 2008 and November 2010 and covered the activities of the case organisation from 2004 to 2010. The data, as summarised in Table 1 below, was collected via interviews, observations, and document analysis.

\section{Insert Table 1 Here}

In 2008 the data collection involved attending three corporate presentations. Two were given by senior managers and the third by a project manager of the finance department, through whom research access was negotiated. These presentations provided us with an initial understanding of the case organisation and covered a wide range of information including the background to the organisation, details of chosen strategy, how competitive advantage was achieved and maintained, and the specific sustainability related issues they faced. Our background understanding was further deepened through a review of publically available data from the internet, annual reports, and sustainability reports.

In 2009 we formerly entered Kiwi to collect data. In total we conducted twenty three and a half hours of interviews with all the relevant actors within the Kiwi network and key actors from associated networks. Performing close to nineteen hours of observations allowed us to deepen our understanding, through seeing first hand key activities in practice. We also viewed and analysed externally and internally available artefacts, including information from websites, the organisations intranet, management reports, traditional management controls (such as budgets) and more issue specific management controls (such as the organisations carbon footprint report and supporting calculative spreadsheets). This data collection and analysis enabled us to develop a good understanding of the core value's travels through time and space.

We took an iterative approach to the analysis, which we began while still collecting the data, in order to ascertain a high level of certainty over the plausibility and validity of our findings (Ahrens and Chapman, 2006, Vaivio, 2008). This approach to data analysis allowed us to exit the field once we were confident that we had met our research purpose. In 2010 we conducted a follow up interview with the Sustainability Initiative Lead for the South Pacific from Eagle, whose role required him to interact with key actors from Koala and Kiwi. This actor's in depth knowledge of Kiwi during the time period under investigation provided us with further confidence over our findings as presented in the following sections.

\section{The Core Value at Kiwi}

While the focus of this paper is on Kiwi's sustainability focused core value as it travelled through time and space it is helpful to start with some of the background context that resulted in it being constructed. This began in early 2004 through many different actors, including the New Zealand government, NGOs, and suppliers, undertaking differing actions to try and place pressure on the senior management of Kiwi, called 'the New Zealand Leadership Team' (NZLT), to act on sustainability issues. However Eagle, Koala and Kiwi's customers 
also undertook actions to act on the NZLT. A video produced by Eagle that they circulated internally within their extended networks is an example of the actors enrolled in their attempts. In this video images of Gandhi, Aung San Suu Kyi and Ang Lee are presented alongside iconic images of Eagle in an effort to prompt those within the extended networks to take action with regards to sustainability issues. This was reinforced through statements like "If we consume what we do today we will need the resources equivalent of 4 planets" and "by redesigning the way we work and live so that sustainability is part of everything we do", images of masses of waste, recycling efforts, renewable energy sources, and making promises to "grow our business, not our carbon", "always reuse the waste we generate", and "give back every drop of water we take".

At the forefront of Koala's efforts to influence the NZLT was the implementing, within Operations, of four KPIs known as the environmental performance metrics (EPM). These four metrics measured water usage, energy usage, waste minimisation, and recycling levels respectively. Koala developed a data collection spreadsheet and required Kiwi to collect and report the results monthly. For many years the effects of the EPMs were limited to data collection within Operations. Despite the emphasis placed by Koala they failed to act upon the NZLT. In Australia water shortage is one of the greatest ecological issues. Therefore, Koala placed most emphasis on the water usage EPM. However in New Zealand water is perceived as a plentiful resource, resulting in the emphasis placed by Koala on the water usage EPM being seen as mostly meaningless for Kiwi[2]. Hence, while data was collected and reported, the EPMs failed to enrol the NZLT into Koala's program of action. Thus, while Koala technically were in control of the NZLT, 'power' is in the hands of those that chose to act (or not) rather than those that make the commands (Latour, 1986).

The NZLT only began to act when they became aware that customers were beginning to question what Kiwi was doing in regards to sustainability issues. The sales reps of Kiwi regularly visit their assigned customers to have a meeting that does not primarily focus on making sales but rather with the aim of gathering market intelligence. This involved spending time discussing with the owner or manager various topics, including their views of future sales, opportunities the customer perceived and issues of various types. When returning to their car the sales reps use their laptop computer to capture information from the discussion by filling out a standardised questionnaire. The answers to the questionnaires are collated in a database that is interrogated by business analysts. A report of key information from this analysis was regularly circulated among the members of the NZLT. Hence in early 2004 the NZLT became aware that consumers were asking their customers questions related to sustainability and they were in turn beginning to ask the sales reps about Kiwis' actions in relation to these questions. Thus many actors, including customers, sales reps, market intelligence, cars, laptop computers, questionnaires, databases, and reports, were assembled together and acted upon the NZLT in a way that Eagle and Koala had done only to a limited degree.

The translation of consumer concerns acted upon the NZLT to start discussing what their response should be. Within these discussions it became apparent that none of the NZLT had much technical proficiency or knowledge in relation to sustainability issues nor did they know whether it existed within Kiwi. However, as the CFO commented:

"You've got to answer the question what's it going to look like because no one can answer what it is. It's an evolving thing and it will be whoever can play hardest in this area that will define what it will become. Whether it's society who plays harder or whether it's business that plays hard will really decide what it actually gets to mean and determine how it looks at the end of it." 
Hence while the technical proficiency or knowledge did not exist within the NZLT they expected gaining it to involve a series of programs and trials of strength over anti-programs. Further, they were aware of a number of high profile organisations within New Zealand who had made claims about their actions in regards to sustainability that had subsequently been disputed and resulted in media exposure with associated loss of reputation and downturn in financial performance. This is exemplified by the CFO:

"If you talk to some companies around town honestly, that have invested heavily, for example a particular energy company, they'll, behind closed doors, say 'how do we get ourselves out of this solution we've created'. They actively are trying to figure out how they divest themselves from these sustainability actions as they've created a position in the market which is then bringing criticism upon them."

This is further elaborated on by the Director of Corporate Affairs who noted:

"So what we didn't want to do is get caught in this whole greening messaging as well. So we've been very cautious. So we got the NZLT together and discussed what do we want to do? Do we want to drive this bus? Or do we want to just see how the whole process goes?"

Thus the NZLT discussed potentially damaging trials of strength emerging out of their efforts to engage with sustainability. However, given the assembling and translation of consumer concerns they also discussed the potentially damaging trials of strength that could emerge through not engaging. They needed to develop a program that would translate these competing matters of concern (Latour, 2005) in a way that would enrol these potential counter-actors into supporting Kiwi. The program that they decided would best balance these competing concerns was to construct a core value around sustainability. The Managing Director stated the core value as "Kiwi wants to be an emerging leader in sustainability".

In order to limit the risks associated with its use, they decided not to include it within any formal vision or mission statements, but rather to communicate it verbally and informally throughout the organisation. However, even as a broad informal control it raised a number of questions. These included what does sustainability issues mean? In the context of the sustainability issues what does it mean to be an emerging leader? Who will judge Kiwi in terms of being an emerging leader in sustainability issues? These questions allowed the NZLT's intentions to be translated into time and space in which many other actors were mobilised to undertake experiments in an attempt to answer them.

One of the first mobilisations was the 2004 hiring of the Corporate Affairs Manager to promote the external image of Kiwi with a particular emphasis on sustainability. A primary objective was the construction of a sustainability report. It was decided that this should be a stand-alone report distinct from the reporting of financial results as Kiwi only reported these in the combined group annual report. The first of these was produced by Kiwi for the 2006-7 financial year and was printed directly on cardboard packaging[3]. This report outlined current achievements and future goals in the four areas, as suggested by Eagle, of marketplace, workplace, community, and environment. However no dedicated information system was set up in order to produce this report. Rather the information was personally gathered by the Corporate Affairs Manager through talking to actors in the areas of interest. This included asking the Integrated Management Systems Manager for the data from the four sustainability focused EPMs. Hence the core value began assembling, corralling and 
enrolling actors around it. These included the corporate affairs manager, cardboard packaging, sustainability reports, and EPMs. However, none of these necessarily related to sustainability, such as planetary boundaries, finite resources, or equity.

Hence the launch of this first report did not provide much in terms of answering the questions raised by the core value. This is unsurprising given that the Corporate Affairs Managers' educational background was in journalism and film rather than ecology or sustainability. Further as the report was focused on external relations it had minimal impact on internal operations. Thus it would seem that, while the core value had started to assemble, corral and enrol others around it, its travels were limited and in relation to marketing and public relations rather than sustainability. As a result the $\mathrm{CFO}$ agreed to become spokesperson (Callon, 1986b) for the core value.

The CFO's first action as spokesperson was the construction of a cross-functional team - the 'Imagineering Team' - that enrolled actors from across Kiwi. The teams' aim was to develop knowledge around sustainability. They were specifically charged with engaging with the questions the new core value posed. In other words they had as their remit to answer the questions as to what is sustainability, what it meant to be an emerging leader in this context, and who the audience was to judge Kiwi as such. Recognising the lack of knowledge within Kiwi, the CFO engaged an outside consulting firm, 'Consult', to assist the Imagineering Team. Consult had previously been engaged to assist with preparation of the sustainability report and had mainly been chosen due to their founder being a previous work colleague of the Corporate Affairs Manager. During the sessions that Consult led with the Imagineering Team they introduced a new market demographic that was put forward as important to Kiwi. This demographic was labelled as 'Lifestyles of Health and Sustainability' (LOHAS) who were seen as conscientious consumers whose purchases were driven by a set of beliefs focused on healthy living and sustainability ideals. Consult provided 'facts' about LOHAS becoming an expanding group which potentially could be a key demographic for Kiwi as commented upon by the CFO:

"LOHAS span all income groups and sits at between thirty to forty percent. So whether they gain momentum and really do mainstream then that will probably be the biggest question."

The result of the Imagineering Team was the assembling, corralling and enrolling of further actors, such as Kiwi staff members, Consult, marketing information, and consumer groups. Notably this focused attention on the potential to enrol, through marketing, a consumer group, LOHAS, and thereby make sales rather than sustainability. Nonetheless, this enabled the core value to continue to travel through time and space.

These travels were further enabled through participants of the Imagineering Team starting to act, across multiple spaces and time, within their respective areas. This research in the wild involved experimenting to ascertain how sustainability related to their daily practices. An example of this is provided by the Procurement / Logistics Manager:

"We've run a session with our suppliers last year. We've invited them openly as part of a formal process called 'The Supply Challenge' to come to us with ideas about how we can make our business more sustainable."

The Procurement / Logistics Manager also had not been formerly educated in relation to sustainability issues. Hence experimentation was a key way for him to develop knowledge in terms of how this related to his area. Thus, along with 'The Supply Challenge', he 
constructed other initiatives, some of which involved enrolling new or modified management controls. Amongst these was the sustainability procurement guideline, which aimed to translate the focus of the core value into actions in relation to procurement. The implementation of the new procurement guidelines acted upon a number of decisions, such as the replacement of the vehicles used by sales representatives. This involved changing the existing fleet of Suzuki Vitaras with more fuel efficient VW Golf 1.9 litre turbo diesel cars. The Procurement / Logistics Manager noted that the reasons for this were:

\begin{abstract}
"So we've actually seen nearly a sixty percent decrease in our fuel cost on the vehicles we've put in. The purchase price of the Golf was higher but the total cost of ownership of the Golf is a lot cheaper because the service intervals are longer. And VW is seen as a leader with their blue motion technology as well. So from market placement it was a good branding opportunity for us as well to use what was seen to be the best leader in the market and align ourselves to them."
\end{abstract}

The procurement guidelines also prompted other actions including swapping to an electricity supplier who generated electricity from only renewable energy sources, light weighting of packaging projects, and exploring new uses for recycled packaging. This shows that yet more actors were being enrolled, such as procurement guidelines, fuel costs, total cost of ownership, blue motion technology, VW cars, electricity suppliers, and packaging, or disavowed, such as Suzuki Vitaras, in order to help the core value travel. However, the Procurement / Logistics Manager noted that while he had an interest in sustainability on a personal level this experimentation was driven by business imperatives and:

"I suppose it's an intrinsic thing for me that I like to be involved with new thinking. I like to be involved with emerging thought. You know I like to challenge. I like to bring in new ideas into the business."

Hence, the core value opened a space and time for the Procurement / Logistics Manager to undertake this research in the wild. The actions that resulted, and allowed the core value to continue to travel, were again in relation to marketing and public relations. However, actors that were starting to be enrolled related to the traditional realm of accounting: cost and profit.

Experiments occurred in multiple times and spaces throughout Kiwi, wherever members of the Imagineering Team were located. This experimentation opened up new possibilities for the core value to travel through providing visibility for it to other actors within Kiwi. This visibility was constructed via many forms such as through direct observation of the experiments or through articles about the experiments in Kiwi's internal magazine.

The core value and the subsequent Imagineering Team also created time and space for a 'workplace activist' (Ball, 2007) to move sustainability issues from being a personal interest to becoming a major part of her role as Project Manager Operations. She explains that prior to the core value and the Imagineering Team her efforts in regards to sustainability issues involved:

"I had what I call my moonlight list and that was just whenever I saw stuff out there, books I was reading, media, whatever, I'd just start writing down good bits that applied here. Some were pretty farfetched. The intention was if I ever got to a point in between projects or where actually I feel like I need to escape from my project for an hour, I'd 
look at my moonlight list and do a little bit on that or in fairness it's probably what kept me here an extra hour or two some nights during the week."

Her opportunity to move this personal interest further began at a senior managers meeting where the core values' spokesperson, the CFO, overviewed how the Imagineering Team was about to be set up. After participating in the Imagineering Team she negotiated, with the backing of the CFO, to be allowed to have a time allocation to devote to sustainability issues. This time allocation included acting as an advocate across Kiwi to enrol further actors and acting as a coordinator to try to bring some form of coherence between the disparate actions taking place in differing times and spaces. However, this proved problematic as she did not have any form of authority to compel people to act as she wanted them to and so she quickly learnt that 'power' belongs to those many that chose to act or not (Briers and Chua, 2001, Latour, 1986). This meant that while the CFO and other members of the NZLT regarded her as the organisational champion in practice a large part of her efforts focused on experiments within her own part of the organisation: operations. As she explains:

"In terms of my doing there's been a little bit of front end customer focusing stuff but probably the part where because of the role I sit in my biggest influence has been around some of that operational improvement stuff such as water use and site recycling."

Hence the core value had enrolled another key actor to help keep it travelling, through opening up the time and space for this workplace activist to engage in actions that previously had been no go areas. However, these actions were mostly within operations, due to her limited success in enrolling others from across Kiwi.

At the beginning of 2008 the core value gained a new supporter, the Managing Director, who took an interest in the experimentation going on within operations. He undertook a review of the four EPMs originally introduced to Kiwi by Koala. While the data was still being collected and reported, these metrics provided little input to the control of the production process or any other process within Kiwi. The Managing Director selected one of the four, waste minimisation, and indicated that this should be the one that all production facilities focus on. The enrolment of this EPM to translate the Managing Director's program had two interrelated effects. It, firstly, mobilised many actors within operations and it, secondly, allowed time and space for them to engage in experimentation.

The EPM measured the percentage of waste produced in the production process that was being recycled or reused in some way. Previously there had been a target for performance set at ninety percent. This had resulted in some experimentation with two production plants, Christchurch and Putaruru, comfortably exceeding the target. The MD enrolled the EPM and translated his program through moving the targeted performance to ninety nine percent. This new target acted upon many and created times and spaces for more research in the wild that again enabled the core value to continue to travel. This can be seen in the changes that occurred at the Christchurch Production Plant. The Christchurch Production Planning Manager's immediate reaction to the new target was:

"I thought these guys need their heads read, no one can get ninetynine, it can't be achieved. So I sent my manager a couple of emails saying that I was pretty hacked off because it's part of but it's not my main job, I've got all my other responsibilities and to have to 
somehow lift those levels, I mean you normally go up in stages don't you, anyone's normal quota would, but I must say they had foresight."

As can be seen, the new target was initially meet with resistance by production planning managers within Kiwi as they believed they had done everything they could with their available resources to be above the original target. However the shifting of the target had two outcomes. The first was that the EPM became embroiled in controversy, a trial of strength, with all levels of operations monitoring and discussing performance against the target. This included production facilities that had poor performance seeking advice from the recognised leaders in this area including the Christchurch Production Planning Manager. Secondly, the new target acted on the recognised leaders, prompting them to scan for opportunities and experiment with innovations in order to improve their performance. In the case of the Christchurch Production Plant the biggest area that needed improvement was dry waste that had no apparent opportunities for reuse. It was collected by traditional waste management services who charged Kiwi to take it to landfill. The new target acted upon the Christchurch Production Planning Manager whose attempts at finding a solution resulted in the discovery of an external organisation that specialised in recycling dry waste. He found this through reading an article about them in the local newspaper (The Press, 2008). With this organisation now collecting the dry waste and recycling up to ninety percent of it, the Christchurch plant had now improved their performance to consistently meet the new target. Hence, this trial of strength created by the EPM acted to construct new opportunities. This created space and time for experimentation that assembled, corralled, and enrolled further actors, such as new targets, the Christchurch Production Planning Manager, emails, newspaper articles, and recycled dry waste, which allowed the core value to continue to travel.

Later in 2008 the core value's spokesperson, the CFO, enrolled another management control in his efforts to allow it to continue to travel. Specifically, he instigated a project to construct a calculation (Callon and Muniesa, 2005), Kiwi's carbon footprint. The CFO enrolled one of his direct reports, the Project Manager Finance, to run the project. In her words the carbon footprint project came about as follows:

"Effectively we looked at what was happening and the potential of the ETS [The New Zealand Government's Carbon Emissions Trading Scheme] coming in as well and what was happening within the group and where things were at. The group was starting to look at carbon footprint for the Australian business but we also wanted to look at it at the same time as opposed to waiting"

The year 2007 was selected as the base year for the project as it was the latest for which complete data was available. Given the complexity of Kiwi, the time frame for detaching entities and reassembling them within a calculative space in order to make the calculation (Callon and Muniesa, 2005) was significantly underestimated. This meant the calculation was completed behind schedule. During this delay many other experiments were underway in different times and spaces within Kiwi. While many actors were being enrolled and knowledge constructed this was disparate, disconnected and partial at best. Hence while change was occurring in relation to the core value it was occurring across multiple spaces and times, was a-centred, and non-rational in focus, or in short, it suffered from 'drift' (Andon et al., 2007, Quattrone and Hopper, 2001). This was compounded by many actors still remaining unenrolled into the program of the core value. Many, such as the CFO and Project Manager Finance, saw the carbon footprint as the construction of a key actor that, through bringing focus and coherence to the many other initiatives, would solidify and make durable 
the network that was being assembled. This would be achieved through the carbon footprint providing answers to the questions that the core value posed, but to this point remained unanswered. That is, it would provide the necessary understanding of sustainability, it would enable Kiwi to become an emerging leader, and it would identify those that would be in a position to judge Kiwi as a leader.

However, the initial calculation of the base year provided surprising results. Prior to the calculation there were expectations that the heaviest carbon (or carbon equivalent) areas, given Kiwi is a manufacturer, would be from the production processes and vehicles used by the sales reps and delivery drivers. This expectation had acted to prompt emission reduction programs solely from these sources. The calculation of the carbon footprint acted upon these programs due to the results it produced. That is, the two areas, production and vehicles, were dwarfed by the total emissions from the refrigeration equipment that Kiwi maintained at their customers that alone made up two thirds of the footprint. The results not only acted upon the emission reduction programs but also acted on the format of the carbon footprint report. That is, the report was expanded to show the results in total and also the results without the emissions from the refrigeration equipment. If the total emissions alone were shown then the refrigeration equipment emissions would dominate the reader's attention. Hence, the remainder of the results were presented separately within the report in order to allow them to have the opportunity to act on the reader.

The carbon footprint and related reports also acted on the Project Manager Finance.

"I mean in the initial stages I possibly approached it a bit more like an accountant in terms of it's a report, it's got numbers coming in one end and graphs and reports coming out the other end. That was very naïve as there is so much more to it. I faced an incredibly complex process to even understand the types of emissions that need to come in here and the different parts of the business that actually create those. It's been a very complex process."

Through calculating the carbon footprint and struggling to come to terms with the way equivalence is created for different gases (MacKenzie, 2009), the ecological literacy (Ball and Milne, 2005) of the Project Manager Finance changed. However, the completion of the calculation did not bring focus and coherence to the many other initiatives, nor did it solidify and make durable the network that was being assembled. While it did assemble, corral and enrol many more actors, such as the Project Manager Finance, the ETS, molecules of gases, and reports, it provided surprises rather than answers to the questions posed by the core value. This enabled the core value to continue to travel but, as it turned out, only for a limited time.

In 2009 a number of events occurred that resulted in the core value losing much of its support, which compromised its ability to travel and resulted eventually in it being abandoned. The core value's spokesperson, the CFO, resigned from Kiwi in March of 2009 in order to take up an opportunity as the CEO of a computer software company. His role as $\mathrm{CFO}$, along with his extended network which included the accounting infrastructure, gave legitimacy to, thereby opening up space and time for, the experiments that had sprung up around the core value. Hence the assembled network was weakened through the loss of an actor who could mobilise a large and important network of actors to support the core values travels.

Prior to the CFO leaving, the spokesperson role for the core value was transferred to the GM of Corporate Affairs. However, she did not have the network that the CFO had to mobilise actors. Further, she also left Kiwi about a week after the CFO, which meant that the 
NZLT had to find another spokesperson. With the GM of Corporate Affairs leaving, her role became disestablished, with the duties being divided between two other members of the NZLT. A sizeable portion of the role was transferred to the GM of Human Resources, who became known as the Director of People and Performance. The NZLT decided that, given that the majority of the duties of the GM of Corporate Affairs had been transferred to her, the Director of People and Performance would become the spokesperson for the core value. However, the Director of People and Performance already had a full work load, and found it difficult to integrate the new duties. Being spokesperson for the core value never became a major priority for her. Without an active spokesperson the core value struggled to act. Without being able to assemble, corral and enrol others around it the core value's ability to travel started to decline.

Later in 2009 the core value faced further trials of strength. One such trial of strength was the Project Manager Finance going on maternity leave in mid-2009. While she was on leave there was no other person appointed to take over the carbon footprint project. Hence the ability of the carbon footprint and associated reports to act stopped until the Project Manager Finance returned from this leave in 2010. However, as we describe below, the outcome of other trials of strength during her absence meant that the core value was abandoned and as a result any actions suggested by the carbon footprint and associated reports were also not a priority.

During the latter part of 2009 the network assembled around the core value was further weakened by the departure of other actors. Specifically the Corporate Affairs Manager and the former Integrated Management Systems Manager (who coordinated efforts around the EPMs), also took maternity leave. Further the Project Manager Operations was reassigned roles within Kiwi from operations to the commercial, sales part of the organisation. With this move she abandoned her moonlight chart and efforts in relation to sustainability to concentrate on learning a new role in a completely different area.

The result of people taking maternity leave and moving roles led to a further weakening of the core values ability to act and continue its travels. The final trial of strength that resulted in the core value being abandoned was that Kiwi was beginning to feel the effects of the 2008/09 economic recession. This particularly came into focus with New Zealand's hosting of the 2011 Rugby World Cup. The decision was taken by the NZLT in early 2010 to reassign all available resources away from other initiatives, such as those around the core value, and put them into maximising the financial benefits that could be gained by Kiwi during this event. While the core value acted upon and enrolled many actors that were in relation to marketing, public relations, cost reductions, and all the things that can affect profit, it had not constructed these in a stable and durable way that could overcome such a trial of strength. Hence, the core value lost its remaining support and in doing so its ability to travel. Thus, the core value was abandoned by Kiwi.

Given our analysis of the events that took place at Kiwi in relation to their sustainability focused core value we now turn in the next section to providing a discussion to link these new understanding back to the literature.

\section{Discussion}

In the previous section we analysed the case study of the core value at Kiwi, which purports to focus on sustainability, as it travelled through time and space. This illustrated how the core value relied upon many actors for it to be constructed, such as videos, market intelligence, consumer questions, and database analytics, and many more to continue its travels, including sales representative's vehicles, the Project Manager Operations, LOHAS, consultants, and dry waste. Therefore we can see that in travelling through time and space the core value did not glide effortlessly but rather required ongoing momentum to be supplied by others, much 
like a rugby ball being passed between players (Latour, 1986). From these varied actors we can see many that fall within our definition of management controls, such as EPMs, questionnaires, sustainability reports, sustainability procurement guidelines, and carbon footprint. However, despite the assembling, corralling and enrolling of these various actors many trials of strength were encountered, which finally resulted in the weakening of this network and the eventual abandonment of the core value.

The case shows that, throughout its travels, the core value acted as a mediator. That is, it affected the way in which others would have acted and the NZLT's intentions were modified in this process (Latour, 1986, Latour, 2005). As it relied upon many others to travel, it needed to modify the way in which they would act in order to enrol them to its program. Hence we see, for example, the Project Manager Operations become a 'workplace activist' and procurement guidelines changed to include sustainability considerations. However, while the introduction of the core value created time and space for these actions to occur, it alone did not act to prompt experimentation. Specifically it took the CFO to become the spokesperson for the core value and the construction of the Imagineering Team before experimentations began to be undertaken. Hence, the core value gained relevance through assembling, corralling and enrolling a network of actors around it (Chua and Mahama, 2007, Mouritsen et al., 2010). This need to continually construct and reconstruct a network for the core value is seen throughout its travels. This is exemplified, for instance, by the Managing Director's selection of one of the four EPMs for operations to focus on and, in turn, to prompt experimentation. The moving of the targeted performance from ninety percent to ninety nine percent redefined, in relation to waste minimisation, what 'success' and 'failure' were. Hence it acted upon the Christchurch Production Planning Manager who enrolled the outside recycling organisation in his efforts to again be 'successful'. This illustrates how these management controls not only assisted in mediating interactions between people (Law, 1992) but also mediates the travels of the core value.

The case study, therefore, highlights how the core value, in its travels, opened up time and space within which action could be undertaken. It allowed actors who had an interest in sustainability issues to step forward and explore what had previously been no go areas. This allowed, for example, the Procurement / Logistics Manager an opportunity to modify the procurement guidelines to include sustainability considerations and to run supplier challenges that sought to identify opportunities in this area. More importantly was the example of the Project Manager Operations. Previous research (Ball, 2005, Ball, 2007) has highlighted how actors, labelled as 'workplace activists', utilised management controls to create space and time for them to undertake their activities. This was the case to a limited degree for the Project Manager Operations who, prior to the core value, enrolled her moonlight chart to organise small and isolated attempts at addressing sustainability issues. However, with the introduction by the NZLT of the core value, and its need to create a network through which to travel, space and time opened up for her to become a 'researcher in the wild' (Callon and Rabeharisoa, 2003). Hence the core value acted to translate small and isolated attempts into activities more formally incorporated within her role. Therefore, along with workplace activist using management controls to create space and time, this highlights how management controls can actively create space and time for actors to become workplace activists. This suggests possibilities for future research that seeks to understand the active role that management controls may take within sustainable development, including how this constructs space and time for the creation of workplace activists.

Such research, for instance, could examine how these types of management controls act in relation to issues raised in the literature, such as the lack of ecological literacy (Ball and Milne, 2005). The case study suggests that certain management controls may act in order to, at least partially, alleviate such concerns. This is exemplified in the calculation of the carbon 
footprint. In order to be able to dislocate and assemble the 'right' actors within the calculative space (Callon and Muniesa, 2005) of the carbon footprint required the Project Manager Finance to assemble 'facts' (Baxter and Chua, 2003) about how molecules of gases are given equivalence (MacKenzie, 2009). Further, the results enrolled the previously ignored refrigeration equipment, which acted upon the Project Manager Finance to alter the very construction of the report and suggested a difference in what the 'correct' future actions should be. This suggests that future research may want to examine how different management controls that focus on aspects of sustainability can assist or deter sustainable development (Ball and Milne, 2005).

The case evidence also raises the question of whether the core value being constructed as an informal management control that was verbally transmitted affected its ability to travel. That is, would the formalisation and inscribing of the core value have made it more durable and stable? While it would be easy to conclude that it would, the case evidence suggests, as noted above, that whatever form it takes it will still require work to make it travel. Without this work it may become like the mission statement at the casino, a sign that acts upon employees to make them wonder what it has to do with their everyday practices or whether it exists as rhetoric to salve the conscious of well paid executives. However, even when the core value was abandoned traces of it remained in other management controls (Andon et al., 2007, Chua and Mahama, 2007) that were created, such as the carbon footprint and the sustainability report, or transformed, such as the waste minimisation EPM and the procurement guidelines.

Regardless of how the core value was configured it was abandoned as a result of being weakened and being confronted with too many trails of strength. Part of this may be down to the network that was constructed around it. That is, it did not mobilise collective action across Kiwi. Rather, it only mobilised individual actors at times and spaces scattered across Kiwi. So while the core value acted to create experimentation, these were in differing pockets within the organisation and did not have a cohesive and coherent overarching approach to coordinate them. However, attempts were made, such as the use of the Imagineering Team, the internal champion, and the carbon footprint project, at bringing the overarching cohesion and coherence. Further, given it did not mobilise collective action across Kiwi, the core values ability to enrol actors that (re)presented sustainability issues and sustainable development, such as planetary boundaries, intra- and inter-generational equity, may have been limited. Rather this suggests it needed to enrol actors, for example sustainability reports, LOHAS, fuel efficiency, waste minimisation, that aligned with profit seeking activities, such as public relations, marketing, and cost reduction.

Hence the core value acted to create activities that were still largely in line with profit seeking (Contrafatto and Burns, 2013, Norris and O'Dwyer, 2004, Spence and Rinaldi, 2014). This may be as a result of the original core value being ambiguous as to what sustainability was and therefore the actors that engaged with it enrolled the support of management controls that still had profit seeking largely as their remit (Ball, 2007, Bebbington and Thomson, 2013). However, the ambiguity was as a result of the NZLT confronting the competing trials of strength providing by consumer concerns and reputation management. Regardless the ambiguity (and potentially the lack of knowledge) prevented specific sustainability related actors, such as planetary boundaries, intra- and inter-generational equity, to be explicitly enrolled. This allowed the ever present actor of profit maximisation to enrol the core value into its own translation (Gray and Milne, 2002). This suggests that while change occurred it is not clear how far this went and whether it was more related to usual financial concerns (Larrinaga-Gonzalez and Bebbington, 2001). Future research may, therefore, examine how such core values can enrol specific sustainability related actors and be prevented from being enrolled into the translation of profit maximisation. However, this research would need to be 
mindful that the translation sought by such a core value may need to align itself with the translation of profit maximisation in order to be able to continue to travel through time and space (Contrafatto and Burns, 2013, Spence and Rinaldi, 2014).

In closing this section, we note that the above analysis of the core value's travels at Kiwi has implications for the suggested future research. Specifically, the core value acting to create activities that were in line with profit seeking suggests that the lack of engagement by the management control literature with sustainability and sustainable development may result from trying to draw out observations from practices that do not exist (Bebbington and Larrinaga, 2014, Bebbington and Thomson, 2013). This has two implications for future research. First, it may first require that the ecological literacy (Ball and Milne, 2005, Birkin, 2000) of practitioners changes in order that such practices are constructed (Contrafatto and Burns, 2013, Unerman and Chapman, 2014). This suggests the need for academics to fulfil their roles as educators as well as researchers. Secondly, in undertaking this research there will be a need to arm ourselves with knowledge of sustainability and sustainable development that draws from beyond the accounting literature (Bebbington and Larrinaga, 2014, Bebbington and Thomson, 2013). We now turn to concluding in the next section.

\section{Conclusion}

The aim of this paper was to follow a sustainability focused core value as it travelled through time and space. Specifically we aimed to examine whether the use of such a core value assists or deters from efforts by organisational actors to implement sustainable development. Our case study shows that it is the continual (re)construction of a supporting network of actors, both human and non-human, that allows the core value to travel through time and space. The network that is constructed gives the very essence to the core value and allows it to act to create space and time for organisational actors to become researchers in the wild. However, the core values reliance on others for it to be able to continue to travel became most apparent when it underwent a number of trials of strength that weakened the network being assembled and eventually led to its abandonment.

The case study highlighted that a management control can create time and space to allow actors to become workplace activists (Ball, 2007). This illustrates the potential for management controls to take an active role within sustainable development. However, despite the opening up of space and time, the actions that resulted were still largely in terms of profit seeking (Contrafatto and Burns, 2013, Norris and O'Dwyer, 2004, Spence and Rinaldi, 2014). That is, without enrolling specific sustainability related actors, such as planetary boundaries, intra- and inter-generational equity, this allowed for profit seeking, an ever present actor, to monopolise and bring the core value into its own translation. Returning to the anecdote that started this paper, what is clear, from what the case study shows, is that much of the first authors' curiosity still remains, suggesting the need for future research in this area.

Notes:

1. All names within this paper have been anonymised to protect the identity of the organisations and individuals involved.

2. In making this statement we note that this is a common perception among New Zealanders (Ministry for the Environment, 2009a), including those within Kiwi, rather than a reflection of the real quality and supply of water within New Zealand. Evidence suggests that potentially this is not actually the case in New Zealand (Ministry for the Environment, 2009c, Ministry for the Environment, 2009b, Verburg et al., 2010)

3. That is, the report was printed directly onto the corrugated cardboard that normally would have been made into boxes used for the transportation of Kiwi's products to their customers. The corrugated cardboard was as if it had been taken directly off the 
production line with logos of the corresponding product visible at places throughout the report. Thus each report was unique in that it depended on which part of the box a certain page was printed onto as to what image (e.g. product logo, barcodes, "please recycle" logos, etc.) is visible below the printing that was superimposed onto it. However, we were informed by the Corporate Affairs Manager that the particular product line that this corrugated cardboard packaging related to had been discontinued and therefore had it not been used for this report then it would have been discarded. 


\section{References:}

Abernethy, M.A. and Chua, W.F. (1996), "A field study of control system "redesign": the impact of institutional processes on strategic choice", Contemporary Accounting Research, Vol 13 No 2, pp. 569-606.

Adler, P.S. and Borys, B. (1996), "Two types of bureaucracy: enabling and coercive", Administrative Science Quarterly, Vol 41 No 1, pp. 61-89.

Ahrens, T. and Chapman, C.S. (2004), "Accounting for flexibility and efficiency: a field study of management control systems in a restaurant chain", Contemporary Accounting Research, Vol 21 No 2, pp. 271-301.

Ahrens, T. and Chapman, C.S. (2006), "Doing qualitative field research in management accounting: positioning data to contribute to theory", Accounting, Organizations and Society, Vol 31 No 8, pp. 819-841.

Akroyd, C. and Maguire, W. (2011), "The roles of management control in a product development setting", Qualitative Research in Accounting \& Management, Vol 8 No 3, pp. 212-237.

Andon, P., Baxter, J. and Chua, W.F. (2007), "Accounting change as relational drifting: a field study of experiments with performance measurement", Management Accounting Research, Vol 18 No 2, pp. 273-308.

Antheaume, N. (2007), "Full cost accounting: Adam Smith meets Rachel Carson?" in Unerman, J., Bebbington, J. and O'Dwyer, B. (eds.) Sustainability Accounting and Accountability, Routledge, London, UK, pp. 211-225.

Arrow, K., Bolin, B., Costanza, R., Dasgupta, P., Folke, C., Holling, C.S., Jansson, B-O., Simon, L., et al. (1995), "Economic growth, carrying capacity, and the environment", Ecological Economics, No 15, No. 2, pp. 91-95.

Ball, A. (2005), "Environmental accounting and change in UK local government", Accounting, Auditing \& Accountability Journal, Vol 18 No 3, pp. 346-373.

Ball, A. (2007), "Environmental accounting as workplace activism", Critical Perspectives on Accounting, Vol 18 No 7, pp. 759-778.

Ball, A. and Milne, M.J. (2005), "Sustainability and management control", in Berry, A.J., Broadbent, J. and Otley, D. (Eds.) Management Control: Theories, Issues, and Performance, Palgrave Macmillan, Basingstoke, UK, pp. 314-337.

Barter, N. and Bebbington, J. (2013), "Actor-network theory: a briefing note and possibilities for social and environmental accounting research", Social and Environmental Accountability Journal, Vol 33 No 1, pp. 33-50.

Baxter, J. and Chua, W.F. (2003), "Alternative management accounting research - whence and whither", Accounting, Organizations and Society, Vol 28 No 2, pp. 97-126.

Bebbington, J. (2001), "Sustainable development: a review of the international development, business and accounting literature", Accounting Forum, Vol 25 No 2, pp. 128-157.

Bebbington, J. and Gray, R. (2001), "An account of sustainability: failure, success and a reconceptualization", Critical Perspectives on Accounting, Vol 12 No 5, pp. 557-588.

Bebbington, J., Gray, R.H., Hibbitt, C. and Kirk, E. (2001), Full Cost Accounting: An Agenda for Action, Association of Chartered Certified Accountants, London.

Bebbington, J. and Larrinaga, C. (2014), "Accounting and sustainable development: an exploration", Accounting, Organizations and Society, Vol 39 No 6, pp. 395-413.

Bebbington, J. and Thomson, I. (2013), "Sustainable development, management and accounting: boundary crossing", Management Accounting Research, Vol 24 No 4, pp. 277-283.

Birkin, F. (2000), "The art of accounting for science: a prerequisite for sustainable development?", Critical Perspectives on Accounting, Vol 11 No 3, pp. 289-309. 
Briers, M. and Chua, W.F. (2001) "The role of actor-networks and boundary objects in management accounting change: a field study of an implementation of activity-based costing", Accounting, Organizations and Society, Vol 26 No 3, pp. 237-269.

Bruining, H., Bonnet, M. and Wright, M. (2004), "Management control systems and strategy change in buyouts", Management Accounting Research, Vol 15 No 2, pp. 155-177.

Byrch, C., Kearins, K., Milne, M.J. and Morgan, R. (2007), "Sustainable "what"? A cognitive approach to understanding sustainable development" Qualitative Research in Accounting \& Management, Vol 4 No 1, pp. 26-52.

Cairns, J. (2001), "Sustainability, exceptionalism, and exemptionalism", Ecosystem Health, Vol 7 No 3, pp. 147-154.

Callon, M. (1986a), "The sociology of an actor-network: the case of the electric vehicle" in Callon, M., Law, J. and Arie, R. (Eds.) Mapping the Dynamics of Science and Technology: Sociology of Science in the Real World, Macmillan, Basingstoke, UK.

Callon, M. (1986b), "Some elements of a sociology of translation: domestication of the scallops and the fishermen of St Brieuc Bay" in Law, J. (Ed.) Power, Action and Belief: A New Sociology of Knowledge?, Routledge, London.

Callon, M. and Law, J. (2005), "On qualculation, agency, and otherness", Environment and Planning D: Society and Space, Vol 23 No 5, 717-733.

Callon, M. and Muniesa, F. (2005), "Economic markets as calculative collective devices", Organization Studies, Vol 26 No 8, pp. 1229-1250.

Callon, M. and Rabeharisoa, V. (2003), "Research "in the wild" and the shaping of new social identities", Technology in Society, Vol 25 No 2, pp. 193-204.

Chua, W.F. and Mahama, H. (2007), "The effect of network ties on accounting controls in a supply alliance: field study evidence", Contemporary Accounting Research, Vol 24 No 1, pp. 47-86.

Contrafatto, M. and Burns, J. (2013), "Social and environmental accounting, organisational change and management accounting: a processual view", Management Accounting Research, Vol 24 No 4, pp. 349-365.

Dent, J.F. (1991), "Accounting and organizational cultures: a field study of the emergence of a new organizational reality", Accounting, Organizations and Society, Vol 16 No 8, pp. 705-732.

Dryzek, J.S. (1997), The Politics of the Earth: Environmental Discourses, Oxford University Press, Oxford, UK.

Everett, J. and Neu, D. (2000), "Ecological modernization and the limits of environmental accounting?", Accounting Forum, Vol 24 No 1, pp. 5-29.

Flamholts, E.G. (1983), "Accounting, budgeting and control systems in their organizational context: theoretical and empirical perspectives", Accounting, Organizations and Society, Vol 8 No 2, pp. 153-169.

Fraser, M. (2012), "“Fleshing out" an engagement with a social accounting technology", Accounting, Auditing \& Accountability Journal, Vol 25 No 3, pp. 508-534.

Gladwin, T.N., Kennelly, J.J. and Krause, T.S. (1995), "Shifting paradigms for sustainable development: implications for management theory and research", The Academy of Management Review, Vol 20 No 4, pp. 874-907.

Gond, J.P., Grubnic, S., Herzig, C. and Moon, J. (2012), "Configuring management control systems: theorizing the integration of strategy and sustainability", Management Accounting Research, Vol 23 No 3, pp. 205-223.

Gray, B. (1990), "The enactment of management control systems: a critique of Simons. Accounting, Organizations and Society, Vol 15 No 1, pp. 145-148. 
Gray, R. (2010), "Is accounting for sustainability actually accounting for sustainability...and how would we know? An exploration of narratives of organisations and the planet", Accounting, Organizations and Society, Vol 35 No 1, pp. 47-62.

Gray, R. and Milne, M.J. (2002), "Sustainability reporting: who's kidding whom? Chartered Accountants Journal of New Zealand, Vol 81 No 6, pp. 66-70.

IPCC 2014. Climate Change 2014: Impacts, Adaptation, and Vulnerability. Part A: Global and Sectoral Aspects. Contribution of Working Group II to the Fifth Assessment Report of the Intergovernmental Panel on Climate Change, Cambridge, United Kingdom and New York, NY, USA, Cambridge University Press.

Justesen, L. and Mouritsen, J. (2011), "Effects of actor-network theory in accounting research", Accounting, Auditing \& Accountability Journal, Vol 24 No 2, pp. 161 193.

Larrinaga-Gonzalez, C. and Bebbington, J. (2001), "Accounting change or institutional appropriation?--A case study of the implementation of environmental accounting", Critical Perspectives on Accounting, Vol 12 No 3, pp. 269-292.

Latour, B. (1986), "The power of associations", in Law, J. (Ed.) Power, Action and Belief: A New Sociology of Knowledge?, Routledge, London.

Latour, B. (1987), Science in Action: How to follow Scientists and Engineers Through Society, Harvard University Press, Cambridge, MA.

Latour, B. (1991), "Technology is society made durable" in Law, J. (Ed.) A Sociology of Monsters: Essays on Power, Technology, and Domination. Routledge, London.

Latour, B. (2005), Reassembling the Social: An Introduction to Actor-Network-Theory, Clarendon, Oxford.

Law, J. (1992), "Notes on the theory of the actor-network: ordering, strategy, and heterogeneity", Systemic Practice and Action Research, Vol 5 No 4, pp. 379-393.

Mackenzie, D. (2009), "Making things the same: gases, emission rights and the politics of carbon markets", Accounting, Organizations and Society, Vol 34 No 3, pp. 440-455.

Miller, P. and Napier, C. (1993), "Genealogies of calculation", Accounting, Organizations and Society, Vol 18 No 7, pp. 631-647.

Milne, M.J. (1996), "On sustainability; the environment and management accounting", Management Accounting Research, Vol 7 No 1, pp. 135-161.

Milne, M.J. (2007), "Downsizing Reg (me and you)! Addressing the 'real' sustainability agenda at work and home", in Mathews, M.R., Gray, R. and Guthrie, J. (Eds.) Social Accounting, Mega Accounting and Beyond: A Festschrift in Honour of M.R. Mathews, The Centre for Social and Environmental Accounting Research, St. Andrews

Milne, M.J. and Gray, R. (2007), "Future prospects for corporate sustainability reporting", in Unerman, J., Bebbington, J. and O'Dwyer, B. (Eds.) Sustainability Accounting and Accountability, Routledge, London.

Milne, M.J., Kearins, K. and Walton, S. (2006), "Creating adventures in wonderland: the journey metaphor and environmental sustainability", Organization, Vol 13 No 6, pp. 801-839.

Ministry for the Environment (2009a), "On tap? Attitudes, behaviours, and perceptions of household water use - informing demand management", Ministry for the Environment, Wellington, available at: http://ndhadeliver.natlib.govt.nz/delivery/ DeliveryManagerServlet?dps_pid=IE1293190\&dps_custom_att_1=ilsdb (accessed 23 March 2015).

Ministry for the Environment, (2009b), "Our rivers: trends in water quality", Ministry for the Environment, Wellington, NZ, available at: http://www.mfe.govt.nz/sites/default/ 
files/media/Fresh\%20water/Our\%20rivers\%20trends\%20in\%20water\%20quality.pdf (accessed 23 March 2015).

Ministry for the Environment, (2009c), "Our water: groundwater quality", Ministry for the Environment, Wellington, NZ, available at: http://www.mfe.govt.nz/sites/default/ files/media/Environmental\%20reporting/Our\%20water\%20groundwater\%20quality. pdf (accessed 23 March 2015).

Mouritsen, J., Hansen, A. and Hansen, C. (2009), "Short and long translations: management accounting calculations and innovation management", Accounting, Organizations and Society, Vol 34 No 6, pp. 738-754.

Mouritsen, J., Mahama, H. and Chua, W.F. (2010), "Actor-network theory and the study of inter-organisational network relations" in Hakansson, H., Kraus, K. and Lind, J. (Eds.) Accounting in Networks, Routledge, New York, pp. 292-313.

Mundy, J. (2010), "Creating dynamic tensions through a balanced use of management control systems", Accounting, Organizations and Society, Vol 35 No 5, pp. 499-523.

Muniesa, F. and Callon, M. (2007), "Economic experiments and the construction of markets", in Mackenzie, D., Muniesa, F. and Siu, L. (Eds.) Do Economists Make Markets?: On the Performativity of Economics, Princeton University Press, Princeton, NJ, pp. 163189.

Nixon, W.A.J. and Burns, J. (2005), "Management control in the 21st century", Management Accounting Research, Vol 16 No 3, pp. 260-268.

Norris, G. and O'Dwyer, B. (2004), "Motivating socially responsive decision making: the operation of management controls in a socially responsive organisation", The British Accounting Review, Vol 36 No 2, pp. 173-196.

Otley, D.T. (1980), "The contingency theory of management accounting: achievement and prognosis", Accounting, Organizations and Society, Vol 5 No 4, pp. 413-428.

Ouchi, W.G. (1977), "The relationship between organizational structure and organizational control", Administrative Science Quarterly, Vol 22 No 1, pp. 95-113.

Ouchi, W.G. (1979), "A conceptual framework for the design of organizational control mechanisms", Management Science, Vol 25 No 9, pp. 833-848.

Owen, D. (2008), "Chronicles of wasted time?: a personal reflection on the current state of, and future prospects for, social and environmental accounting research", Accounting, Auditing \& Accountability Journal, Vol 21 No 2, pp. 240-267.

Pitkänen, H. and Lukka, K. (2011), "Three dimensions of formal and informal feedback in management accounting", Management Accounting Research, Vol 22 No 2, pp. 125137.

Pratt, J. and Beaulieu, P. (1992), "Organizational culture in public accounting: size, technology, rank, and functional area", Accounting, Organizations and Society, Vol 17 No 7, pp. 667-684.

Quattrone, P. and Hopper, T. (2001), "What does organizational change mean? Speculations on a taken for granted category", Management Accounting Research, Vol 12 No 4, pp. 403-435.

Rockström, J., Steffen, W., Noone, K., Persson, Å., Chapin, F.S., Lambin, E.F., Lenton, T.M et al. (2009), "A safe operating space for humanity." Nature, Vol 461 No 7263, pp. 472-475.

Simons, R. (1994), "How new top managers use control systems as levers of strategic renewal", Strategic management journal, Vol 15 No 3, pp. 169-189.

Simons, R. 1995. Levers of Control: How Managers use Innovative Control Systems to Drive Strategic Renewal, Harvard Business School Press, Boston, MA.

Simons, R., Mintzberg, H. and Basu, K. (2002), "Memo to CEOs: the five half-truths of business." Fast Company, No 59 (June), pp. 117-121. 
Spence, L.J. and Rinaldi, L. (2014), "Governmentality in accounting and accountability: a case study of embedding sustainability in a supply chain", Accounting, Organizations and Society, Vol 39 No 6, pp. 433-452.

Tessier, S. and Otley, D. (2012), "A conceptual development of Simons' levers of control framework", Management Accounting Research, Vol 23 No 3, pp. 171-185.

The Press. (2008), "Waste recovery plant kind to environment", 12 March, p.2.

Tuomela, T.S. (2005), "The interplay of different levers of control: a case study of introducing a new performance measurement system", Management Accounting Research, Vol 16 No 3, pp. 293-320.

Unerman, J. and Chapman, C. (2014), "Academic contributions to enhancing accounting for sustainable development", Accounting, Organizations and Society, Vol 39 No 6, pp. 385-394.

Vaivio, J. (2008, "Qualitative management accounting research: rationale, pitfalls and potential", Qualitative Research in Accounting \& Management, Vol 5 No 1, pp. 6486.

Verburg, P., Hamill, K., Unwin, M. and Abell, J. (2010), "Lake water quality in New Zealand 2010: status and trends", in National Institute of Water and Atmospheric Research Ltd (Eds.), Hamilton, NZ.

Wackernagel, M. and Rees, W.E. (1996), Our Ecological Footprint: Reducing Human Impact on the Earth, New Society Publishers, Gabriola Island, B.C.

Whiteman, G., Walker, B. and Perego, P. (2013), "Planetary boundaries: ecological foundations for corporate sustainability", Journal of Management Studies, Vol 50 No 2, pp. 307-336.

Widener, S.K. (2007), "An empirical analysis of the levers of control framework", Accounting, Organizations and Society, Vol 32 No 7, pp. 757-788.

World Commission on Environment and Development. (1987), Our Common Future, Oxford University Press, Oxford.

WWF - World Wild Fund for Nature, (2014), "Living planet report 2014: species and spaces, people and places", Gland, Switzerland.

Xing, Y., Horner, R.M.W., El-Haram, M.A. and Bebbington, J. (2009), "A framework model for assessing sustainability impacts of urban development", Accounting Forum, Vol 33 No 3, pp. 209-224. 


\begin{tabular}{|l|c|c|}
\hline \multicolumn{2}{|c|}{ Internal Data } & Publically Available Data \\
\hline Corporate presentation attended & & 3 \\
\hline Interview hours & 23.5 hours & \\
\hline Number of interviews & 23 & \\
\hline Observation hours & 19 hours & \\
\hline Number of observations & 18 & 64 \\
\hline Documents: & 51 & 3 \\
\hline General artefacts & 4 & 55 \\
\hline Media & 13 & \\
\hline Notes & 46 & \\
\hline
\end{tabular}

TABLE 1

Summary of Data 